\title{
Evaluation of expert reports filed for urgent expropriation: The case of Gelemen and Tekkeköy logistics center*
}

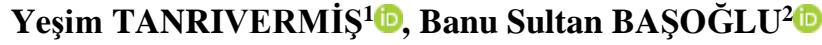 \\ ${ }^{1}$ Ankara University, Faculty of Applied Sciences, Department of Real Estate Development and Management, 06590, Ankara \\ ${ }^{2}$ Ankara University, Graduate School of Natural and Applied Sciences, Department of Real Estate Development and Management, 06590, Ankara \\ Corresponding author: Y. Tanrivermiş, e-mail: aliefendioglu@ankara.edu.tr \\ Author(s) e-mail: banu-aksu@hotmail.com
}

\section{ARTICLE INFO}

Received: September 30, 2021

Received in revised form: November 11, 2021

Accepted: November 11, 2021

\section{Keywords:}

Urgent expropriation

Real estate valuation

Expert witness

Quality of valuation report

Logistic center

\begin{abstract}
In this study, the expert reports received from the court for 51 real estate parcels over the past 20 years have been examined and evaluated. The expert reports are from the urgent expropriation process as per Article 27 of the Expropriation Law No.2942, and these reports have frequently been used by public institutions. In expropriation cases, the income valuation method was used by the real estate experts. It has revealed that the zoning and usage characteristics of the real estate parcels were not taken into consideration sufficiently during valuation, the parameters used in the valuation of the real estate by the expert committee and the determination of structures, facilities and plants on the real estate parcels were incomplete. Important mistakes were made in updating the sales values of comparable real estate parcels and, in general, the quality of the valuation study remained at a low level. In order to minimize these errors, members of the expert committees should be trained and should possess sufficient experience in the field of land acquisition, expropriation and valuation. In these conditions, the valuation studies should be carried out by real estate development experts and the employment of the said experts should be made obligatory in all public institutions and companies that provide consultancy services to them. Furthermore, it is necessary and beneficial to establish a monitoring-evaluation system with the effective supervision of the expertise process.
\end{abstract}

*This article is produced from the term project titled "Expert Reports Analysis in the Process of Expropriation and Determination of Valuation within the Scope of Article 27: Example of Gelemen and Tekkekoy Logistic Center Railway Connection Line”, which is conducted by Banu Sultan Başoğlu and completed under the consultancy of Assoc. Prof. Dr. Yeşim Tanrıvermiş.

\section{Introduction}

Land acquisition for investment projects cannot be achieved by means of purchasing, barter and/or transfer of the real estate in question; therefore, real estate acquisition or confiscation through different expropriation methods (i.e., purchase, full expropriation, partial expropriation, establishment of easement rights, urgent expropriation) become inevitable and valuation procedures constitute the main subject of disputes in practice in expropriation processes. Determination of real estate values is required for the realization of investments and the resolution of disputes (Aç11 1977, Tanrıvermiş et al. 2011a,b, Tanrıvermiş and Aliefendioğlu 2019a,b).

In Turkey, especially in investment projects, the value of real estate in the investment areas or routes are determined by the expert committees within the scope of Article 27, and not examining all the advantage and disadvantage aspects of the real estate negatively affects expropriation processes. The foremost of the problems encountered in the determination of the expropriation prices is whether the prices determined by the expert committees reflect the real price or not. However, not all of the positive and negative aspects affecting real estate values are taken into account by expert committees whilst evaluating real estate. Also, the real estate values are not determined in the light of laws and scientific studies have caused increases in the costs of investment projects. Since the costs determined by expert committees in urgent expropriation price determination cases affect the values in price appreciation determination and registration cases pursuant to Article 10 of the Law No. 2942, the determined costs within the scope of Article 27 are important regarding the feasibility of investment projects in Turkey. In this study, a total of 105 real estate (or parcels) is evaluated, 5 of which are in the Aşağıçınik neighborhood and 100 of them are in the Tekkeköy neighborhood. The main objective of the study was to examine the prices determined by expert committees in accordance with Article 27 of Expropriation Law No. 2942, amended by the Law No. 4650 of 2001, to reveal the effect of the values appropriated as such on the expropriation process, and to determine the effect of expert reports on price.

\section{Materials and Methods}

The material of the study consists of information obtained through literature review; data collected through surveys, interviews, counting and measurement in the study and the surrounding settlements within the boundaries of the Gelemen and Tekkeköy Logistics Center Railway Connection Line Project and data obtained from public institutions and organizations. In the study, the expropriation plan bases of the Gelemen and Tekkeköy Logistics Center Railway Connection Line Project 
were obtained and the bases were superimposed with satellite images.

A parcel-based assessment form was prepared to collect data for the real estate subject to expropriation. The assessment form, which includes all factors that may affect the value of the real estate, such as the use of municipal services and the distance to the nearest province, district, village or road, was prepared at the parcel level and applied. In the study area, 51 real estate parcels with land status, for which the lawsuits under Article 27 were filed, identified at the parcel level and in line with the data obtained. The value of these properties was appraised and a questionnaire form was developed in accordance with the scope and purpose of the study.

The data on rural/urban land and lot markets has not generally been recorded and in the absence of a sound registration system, the main data collection method is surveys (Yang 1986, Ventolo and Williams 2001, Tanrıvermiş et al 2004). In the neighborhood within the scope of the study, interviews were held about the sales values and characteristics of the lands with the owners and/or operators of the lands who actually bought and sold. In the study, records and studies of real estate offices trading in the market, local governments, and other public and private institutions operating in the study area were also used.

In the real estate valuation studies, it is necessary to systematically examine the properties of real estate, to classify them, to collect and analyze data and to estimate their final values for different purposes. In the selection of employed valuation methods, the factors such as the purposes of the valuation, legal regulations, properties of the real estate and market conditions must be considered together. Market values such as comparative sales analysis (equivalent or fair value), subtraction technique (conversion value), replacement price and shadow project, income value, cost value, development analysis and mixed methods are traditionally used in valuation studies (Çağan 1977, Murray et al. 1983, Tanrıvermiş et al. 2004, Tanrıvermiş 2017). In this study, the income valuation method was used for the expropriation cases reports. In valuation based on the cost method, the cost of rebuilding the buildings on the real estate under the economic conditions on the valuation date, the age of the building, and the wear rates are taken into consideration. In the cost analysis, the cost of all materials used in construction, the net costs of special construction and systems (cost minus accumulated depreciation) are considered. In this study, the cost prices of the buildings were determined by considering the approximate cost prices of the buildings in 2018, the depreciation rates of the Ministry of Finance, and the current state of the buildings. In the examination for the determination of the expropriation value, the classes of the structures should be clearly shown and their qualities should be stated (Tutar and Pulak 2006, Tanrıvermiş et al. 2011a, b).

The conversion of a cadastral parcel, which is included in the implementation development plan, into a zoning parcel by making arrangements in accordance with the Zoning Law and related regulations is called "parceling". A real estate that has been converted into a zoning parcel in this way is considered a land plot (Köktürk and Köktürk 2016, Tanrıvermiş 2017). There were 51 real estate in the study area and all these real estate parcels have gained land plot status.

As the real estate examined have acquired the status of land plot, it has been legally obligatory to determine the values of real estate in the form of land plot as per the comparative sale analysis method. In the valuation of the real estate that will be partially or completely expropriated, an attempt has been made to find unstructured or empty precedents as much as possible, and for this purpose, similar precedents have been identified for the valued real estate. The actual purchase and sale values of the determined comparable properties were updated by applying the Domestic Producer Prices Index (D-PPI) $(2003=100)$ of the Turkish Statistical Institute (TURKSTAT)' and the land plot unit values were moved to the transaction date or the valuation date (January 2019). Principally, after determining the average equivalent value with the prices for the period of January 2019, the differences, superior features and deficiencies in terms of all positive and/or negative characteristics revealed by the separate examination of the valued real estates were evaluated one by one. The effects of each of these qualities and differences on the value of the real estate have been determined, and the values of the subject real estate have been appreciated based on the comparison made in this way.

The distances of the precedent used in the appraisal and the subject real estate to each other and to the main axes as well as the distances of the precedent and the subject real estate from the district center (for example, distance to trade and business centers) were determined by using the digitized bases in the computer environment.

\section{Results}

\subsection{Examination of the precedent parcels in the Tekkeköy neighborhood}

In the study area, 2 precedent parcels were determined for the valuation within the borders of Tekkeköy neighborhood, which are subject to expropriation. The construction conditions and zoning characteristics of these precedents differ, and accordingly, the purchase and sale values per unit of the total construction area also change. The real estate that has acquired the status of land were appraised according to the comparative sales analysis (equivalent value) method. In this method, the market price data of the real estate or its precedent are used directly in the valuation of the real estate (Denyer-Green 1998, Ventolo and Williams 2001). The surface areas of the comparable real estate are different from each other and there are differences in their quality and uncertainties and, the construction conditions are variable. For this reason, it is seen that there is a significant variation among the precedent properties in terms of the purchase and sale values per unit of the total construction area. It is observed that the average purchase and sale values of the precedent identified in the neighborhood was between $302.59 \mathrm{TL} \mathrm{m}^{-2}$ and 758.72 TL m ${ }^{-2}$ (Table 1).

The satellite image of the real estate in the study area and the real estate selected as appropriately comparable for valuation are shown in Figure 1. In the decisions of the Court of Cassation, the points to be considered in "selection of precedent" are stated as follows: According to subparagraph $(\mathrm{g})$ of Article 11 of the Expropriation Law, the real estate to be compared must be a precedent for the real estate subject to the lawsuit in the land plots. As can be understood from the meaning of the word, the comparable real estate must be of a quality that can set a sample for the real estate subject to the lawsuit. 
Table 1. Data on comparable properties in Tekkeköy neighborhood of Samsun Province, Tekkeköy District.

\begin{tabular}{lll}
\hline Data and Correction Factors & $1^{\text {st }}$ Sale & $2^{\text {nd }}$ Sale \\
\hline Block /Parcel \# & $159 / 7$ & $1052 / 6$ \\
\hline Registration at the Land Registry & Yes & Yes \\
\hline Sales Value Declared in the Land Registry (TL) & 35000.00 & 520000.00 \\
\hline Type on Deed & Land Plot & Masonry Structure and Land Plot \\
\hline Neighborhood/Village & Tekkeköy & Tekkeköy \\
\hline Plot Size (m ${ }^{2}$ ) & 209.85 & 1216.00 \\
\hline Actual Selling Price (TL) & 35000.00 & 520000.00 \\
\hline Date of Sale & 05.13 .2014 & 02.27 .2015 \\
\hline PPI (Valuation Date, January 2019) & 424.86 & 424.86 \\
\hline PPI (On Sale Date) & 234.18 & 239.46 \\
\hline Sales Value at the Valuation Date, TL (January 2019) & 63498.59 & 922605.86 \\
\hline Unit Value on the Valuation Date (TL m $\left.{ }^{-2}\right)$ & 302.59 & 758.72 \\
\hline Description & $\begin{array}{l} \\
\text { Residential+commercial area, }\end{array}$ \\
\hline
\end{tabular}

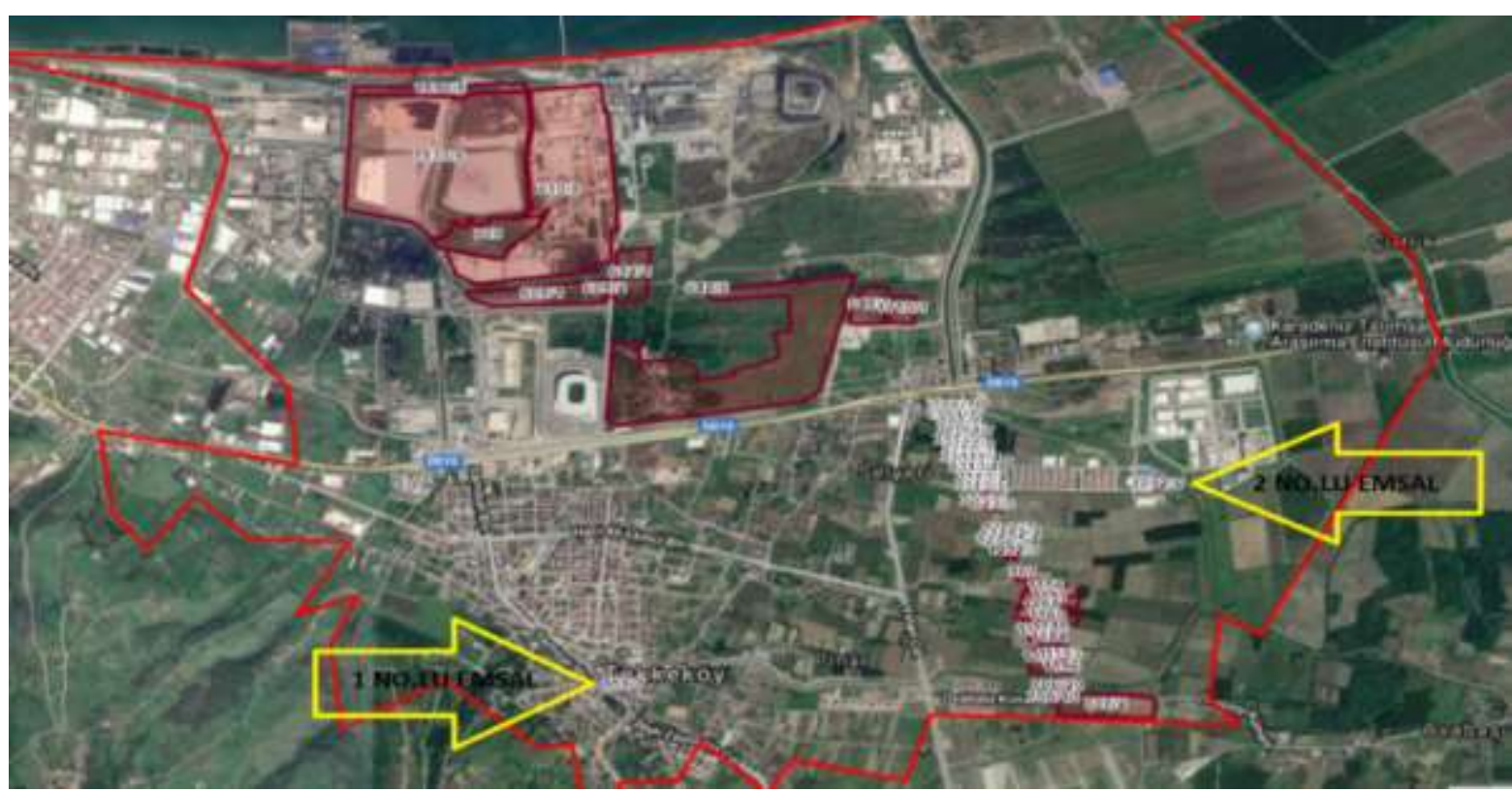

Figure 1. Satellite image of comparable and real estate in the study area (TKGM 2019).

Due to the differentiation of the zoning functions and construction conditions of the examined comparable real estate, adjustments were made on the data related to the precedent parcel. In the Tekkeköy neighborhood, the zoning features of the comparable property \#7 on block 159 were determined as residential and commercial area with 5 stores in an adjoining structure, while the comparable real estate \# 6 on block 1052 in the Tekkeköy neighborhood was determined as a commercial area with a maximum height $\# 10 \mathrm{~m}$. As there is no precedent with the same characteristics due to the problem of buying and selling in the region, the precedent has been adjusted by considering the construction conditions and functions of the 2 real estate parcels determined as comparable. It has been decided that if the real estate \#7 on block \#159, which is taken as comparable to number one, was used as a residential area in its entirety, there may be a $10 \%$ drop in value from the unit price. It has been decided that if the real estate \#6 on block \#1052, which is taken as comparable to number two, was used as a residential area in its entirety, there may be a $35 \%$ drop in value from the unit price. The average comparable value obtained after the correction over the updated sale values of the comparable real estate was determined as
272.33 $\mathrm{TL} \mathrm{m}^{-2}$ for real estate \#1 and 493.17 $\mathrm{TL} \mathrm{m}^{-2}$ for real estate \#2 and the average comparable value was calculated as 382.75 $\mathrm{TL} \mathrm{m}{ }^{-2}$ and the valuation study was completed based on this value.

\subsection{Appraisal of unit values and total value of real estate}

A precedent correction was made in the Tekkeköy neighborhood, and the parameters used in the precedent correction and the possible positive and/or negative effects of these parameters on the value were determined based on the impact scores in the results of the market research conducted in the surrounding area (Table 2). A total of 51 real estate parcels within the borders of the Tekkeköy neighborhood in the study area, which will be partially and completely expropriated, have been appraised. The project line of the real estate that fall in the study area has been superimposed with the satellite images. Since the real estate examined and the comparable real estate parcels do not have similar properties in terms of zoning (cadastral parcels), it has been obligatory to make a reduction on the parcel area or value at the rate corresponding to the regulation 
Table 2. Factors that may cause an increase or decrease in the market value of the appraised real estate in Tekkeköy neighborhood compared to comparable parcels, and their average impact scores

\begin{tabular}{|c|c|}
\hline Value Correction Parameters & Correction Factors (\%) \\
\hline Allocation of the real estate subject to expropriation as a road (decrease in value) & 35 \\
\hline Proximity to the sea of the real estate subject to expropriation compared to comparable parcels (increase in value) & 10 \\
\hline Allocation of the real estate subject to expropriation as a park area (decrease in value) & 30 \\
\hline Allocation of the real estate subject to expropriation as an industrial area (increase in value) & 25 \\
\hline Allocation of the real estate subject to expropriation as a tourism area (increase in value) & 10 \\
\hline The real estate subject to expropriation is facing the road (increase in value) & 10 \\
\hline Unlike the comparable land plot, no DOP is applied to the land in question (decrease in value) & 40 \\
\hline That the real estate subject to expropriation becomes a channel (decrease in value) & 35 \\
\hline The real estate subject to expropriation is public (Treasury) property (decrease in value) & 40 \\
\hline The high density of construction at the location of the real estate subject to expropriation (increase in value) & 50 \\
\hline Allocation of the real estate subject to expropriation as a park and forest area (decrease in value) & 35 \\
\hline $\begin{array}{l}\text { The real estate subject to expropriation is in a central location (transportation/socio-cultural areas) compared to } \\
\text { comparable parcels (increase in value) }\end{array}$ & 20 \\
\hline $\begin{array}{l}\text { The real estate subject to expropriation is in a central location (socio-cultural areas) compared to comparable } \\
\text { parcels (increase in value) }\end{array}$ & 10 \\
\hline $\begin{array}{l}\text { The real estate subject to expropriation is not in a central location (transportation, etc.) compared to comparable } \\
\text { parcels (decrease in value) }\end{array}$ & 20 \\
\hline $\begin{array}{l}\text { The real estate subject to expropriation is not in a central location (transportation, etc.) compared to comparable } \\
\text { parcels (decrease in value) }\end{array}$ & 25 \\
\hline $\begin{array}{l}\text { The real estate subject to expropriation is not in a central location compared to comparable parcels (decrease in } \\
\text { value) }\end{array}$ & 20 \\
\hline $\begin{array}{l}\text { The real estate subject to expropriation is not in a central location compared to comparable parcels (decrease in } \\
\text { value) }\end{array}$ & 30 \\
\hline $\begin{array}{l}\text { The real estate subject to expropriation is not in a central location compared to comparable parcels (decrease in } \\
\text { value) }\end{array}$ & 10 \\
\hline Due to the proximity of the real estate subject to expropriation to the road (increase in value) & 10 \\
\hline The real estate subject to expropriation becomes a non-registered road (decrease in value) & 40 \\
\hline The real estate subject to expropriation becomes a non-registered park (decrease in value) & 35 \\
\hline The real estate subject to expropriation becomes a port back area (decrease in value) & 40 \\
\hline
\end{tabular}

partnership share. Within the scope of the study, the comparable value in Tekkeköy neighborhood is $382.75 \mathrm{TL} \mathrm{m}^{-2}$ and it has been determined between $160.76 \mathrm{TL} \mathrm{m}^{-2}$ and $631.54 \mathrm{TL} \mathrm{m}^{-2}$ considering the positive and negative characteristics of the real estate subject to expropriation.

The total 51 real estate subject to expropriation were appraised at the parcel level, and by using these values, it was decided to purchase them within the scope of Article 8 of Law No. 2942 as amended by Law No. 4650. A compromise could not be reached in the purchase transactions and the administration filed urgent expropriation cases under Article 27. The valuation reports prepared by the relevant institution in urgent expropriation cases are important as they are used as a reference point for expert committees. It was determined that 5 of the 51 real estate parcels examined in the study area had structures, 15 of them had trees and 35 real estate parcels were completely empty. A total value of 63915709.20 TL was appraised for the 51 real estate, the ground value of which was $61975669.52 \mathrm{TL}$, the structure cost was $727633.80 \mathrm{TL}$, and the tree cost was 6872.77 TL. In the study area, $145439.66 \mathrm{~m}^{2}$ of the real estate have been subject to expropriation, and the average floor price has been determined as $426.13 \mathrm{TL} \mathrm{m}^{-2}$, and the total average unit price, including the building and trees, as $439.47 \mathrm{TL} \mathrm{m}^{-2}$.

\subsection{Valuation process of building types}

Building structures were identified in 5 of the 51 real estate parcels in the study area, and these structures were calculated over the approximate unit costs of the building to be used in the calculation of architectural and engineering service costs. The value to be added to the ground value of the real estate, if any, of the structure on the real estate constitutes the net cost value.

The area of the reinforced concrete observation tower is $24.00 \mathrm{~m}^{2}$ and it has been determined that it should be among the Class I, Group A structures in the official unit price chart. According to the results of the determination and market research, no increase or decrease in the value of the reinforced concrete observation tower on the real estate was calculated, and the total present value of the building was found to be 3672.00 TL. Since the reinforced concrete structure is 10 years old, the depreciation cost over 10\% depreciation rate was taken as 367.20 TL and the net present cost value was determined as 3304.80 TL. The area of the reinforced concrete warehouse is $184.20 \mathrm{~m}^{2}$ and it has been determined that it should be among the Class I, Group B structures in the official unit price chart. According to the results of the determination and market research, it has been determined that there may be a $10 \%$ decrease in the cost value due to the neglected and incomplete manufacture of the reinforced concrete warehouse on the property, and the total present value of the structure was found to be 4199.76 TL. Since the reinforced concrete structure is 10 years old, the depreciation cost over $10 \%$ depreciation rate was taken as $3779.78 \mathrm{TL}$ and the net present cost value was determined as $34018.06 \mathrm{TL}$. The area of the concrete ground is $4445.00 \mathrm{~m}^{2}$ and it has been determined that it should be among the class I, group A structures in the official unit price chart. According to the results of the determination and market research, no increase or decrease in the value of the concrete ground on the real estate was calculated, and the total present value of the building was found to be $680085.00 \mathrm{TL}$. Since the concrete structure is 10 years old, the 
depreciation cost over $10 \%$ depreciation rate was taken as 68008.50 TL and the net present cost value was determined as $612076.50 \mathrm{TL}$.

\subsection{Comparison of the costs in the expert reports prepared in accordance with Article 27 and the prices in the valuation reports regarding the study area and suggestions for solutions}

Regarding the 51 real estate parcels among the real estate that fall into the study area, of which purchase was not successful within the scope of Article 8 of the Law No. 2942 amended by the Law No. 4650, urgent expropriation lawsuits were filed and expert reports were prepared for each real estate within the scope of Article 27 of the same law. A comparison was made of the zoning characteristics of the real estate covered by the expert reports and the valuation reports. In the expert reports, it was determined that all of the real estate have acquired the status of land plots. When 51 real estate parcels that were expropriated in the study area were examined, it was confirmed that all real estate has acquired the status of land plot. An examination of the zoning characteristics of the real estate indicated that there was no difference between the zoning properties of the real estate and the results of the study in the expert reports.

As a result of the expert committee's determination based on their own subjective opinion of whether or not the regulation partnership share was deducted from the real estate \#6 on block \#1873 without relying on any official documents, the board of experts made a significant mistake in calculating the price of the real estate. While there was no difference in 50 of the 51 real estate parcels in the study area, in terms of land and land plot distinction and zoning characteristics, it was ignored that the regulation partnership share was deducted in the calculation of the values of the real estate \#6 on block \#1873. A comparison of the properties in the expert reports and the valuation reports in terms of structures and outbuildings was made. The determination of the real estate has an important place in the evaluation of real estate that will be subject to expropriation. In the determination of real estate, it is necessary to determine the area of the real estate subject to expropriation, the trees of different ages and types in this area, and the structures in accordance with Article 11 of the Expropriation Law. The real estate in question should be evaluated in accordance with the same law.

According to the results of the study, it was determined that there were 5 buildings and 15 trees in the 51 real estate parcels in the study area. In the determinations made by the court in April 2019 , it is noteworthy that no trees and structures were identified regarding the real estate subject to expropriation. While calculating the expropriation value, it is necessary to calculate not only the ground value, but also the value of the structures and trees on it. From the point of view of beneficiaries, it is a significant problem that this calculation was overlooked. While the objections to the incomplete determination of the already attached structures on the real estate have an important place in the determination of the expropriation prices in Turkey, the fact that the attached structures on the real estate were not taken into account in the relevant project makes the accuracy of the expert report questionable. According to the results of the study, the attached structures with a value of $734506.57 \mathrm{TL}$ on the total real estate, including the buildings with a value of $727633.80 \mathrm{TL}$ and trees with a value of $6872.77 \mathrm{TL}$, were ignored by the expert committee as part of the calculations.
In the study, the same comparable parcel was used for all of the real estate as all the 51 real estate parcels subject to expropriation are on the same route. For the valuation to be made within the scope of the study, 2 precedents, which have been the subject of real purchase and sale transactions, were found and the average comparable value was determined as $382.75 \mathrm{TL} \mathrm{m}^{-2}$. The precedent value stated has been confirmed as a result of discussions with real estate offices and build-sell offices in the region. While the expert committees formed for the 51 real estate parcels in the study area are different, it is understood that the precedent for the real estate was the same. The expert committees have chosen one comparable parcel, and due to the different valuation dates, the unit comparable value has been taken as 1284.34 TL, 1287.91 TL and 1289.91 TL. Although the expert committee conducted the valuation processes on different dates, the Wholesale Price Index (WPI) on 03.03.2015, which is the date of the purchase and sale of the real estate, was taken differently.

It has been determined that the expert committees' updating the determined comparable over the Wholesale Price Index (WPI) and not using the Domestic Producer Price Index (D-PPI) in the update is contrary to judicial decisions. In the determination of the unit prices determined by the expert committees in the study area, the scoring method was used for the real estate. The unit costs were found by dividing the coefficient obtained as a result of the scoring by the comparable value. In the scoring made by the expert committee, the reason for the scores given for the case in question was not explained. In the scoring of the real estate, as depicted in Figure 2, it has been determined that different expert committees use different scoring for the real estate that are next to each other and have the same features. Different expert boards made the calculations in different ways and whilst one expert board gave 20 points to the possibility of constructing buildings according to their zoning status in the scoring, they used for real estate \#1 and \#2 on block \#609 with the same characteristics, whereas, the other expert board did not use the mentioned parameter (Table 3, Table 4).

The fact that the parameters used in the valuation of the real estate by the expert committees do not overlap with each other reveals that the values of the real estates were determined far from reality. Even the differentiation of the main parameters to be used for two adjacent properties with the same characteristics makes the realism of the expert reports questionable.

The fact that the panel of experts determines different parameters for two real estate parcels with the same characteristics using the same comparable parcel, as can be seen in Table 3 and Table 4, and that scoring is done over these parameters clearly shows that the real market value of the real estate cannot be reflected accurately.

According to the results of the study, the total title deed area of the 51 real estate parcels is $2189926.92 \mathrm{~m}^{2}$, the expropriated area is $145439.66 \mathrm{~m}^{2}$, and the remaining area is $2044487.26 \mathrm{~m}^{2}$ whereas the comparable value determined in the expert report ranges between $1284.34 \mathrm{TL} \mathrm{m}^{-2}$ and $1289.91 \mathrm{TL} \mathrm{m}^{2}$, and the comparable value was found to be $382.75 \mathrm{TL} \mathrm{m}^{-2}$. According to the expert's report, an adjustment was made in the comparable parcels value, taking into account all the positive or negative features found for the real estate and the comparable value varies between $216.00 \mathrm{TL} \mathrm{m}^{-2}$ and $650.00 \mathrm{TL} \mathrm{m}^{-2}$, and the adjusted comparable value calculated according to the study results varies between $160.76 \mathrm{TL} \mathrm{m}^{-2}$ and $631.54 \mathrm{TL} \mathrm{m}^{-2}$. While the total floor price calculated according to the expert's report was 72447603.55 TL, the total floor price calculated based on the 


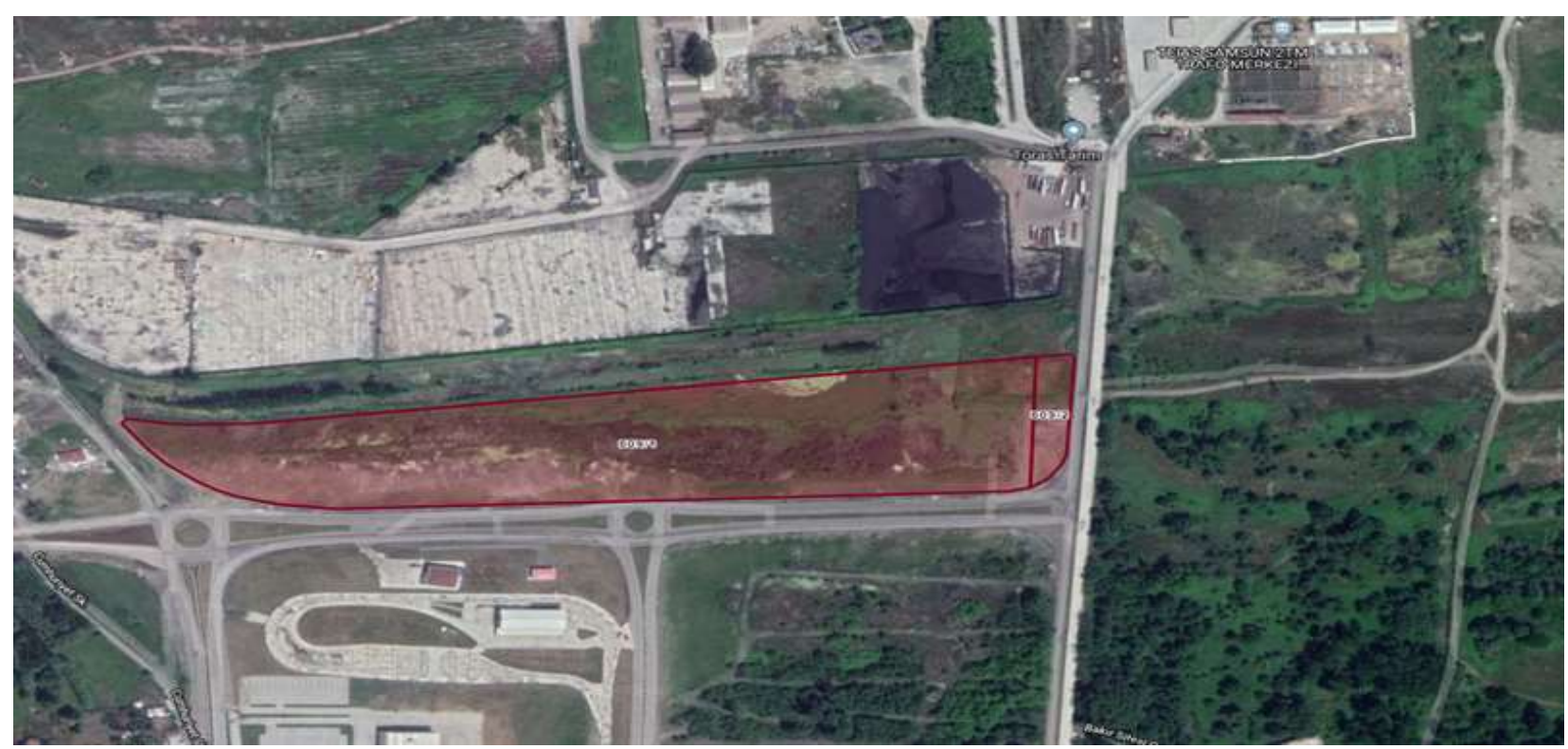

Figure 2. Satellite image of 609 blocks and 1 and 609 blocks and 2 parcels in the study area (TKGM 2019).

Table 3. Parameters and scoring used for block \#609 and real estate \#2

\begin{tabular}{lcc}
\hline Comparison Criteria for Comparable Real Estate Subject to Litigation & Score of Comparable Parcel & $\mathbf{6 0 9 / 2}$ \\
\hline Possibility of Building Based on Zoning Status & 35 & 20 \\
\hline Utilization of Water, Electricity, Infrastructure and Energy Services & 10 & 7 \\
\hline Area Size That Makes Sale Attractive & 3 & 5 \\
\hline Geometric Shape of the Parcel, Construction Status & 3 & 3 \\
\hline Distance to Public Institutions and Organizations, City Center and Social and Economic & 10 & 5 \\
\hline Activity Buildings & 5 & 3 \\
\hline Availability and Ease of Access to Ring Roads & 30 & 3 \\
\hline Preference Based on Commercial Features & 4 & 4 \\
\hline Population Density in the Region and Distance to Schools, Religious Facilities, Settlements & $\mathbf{1 0 0}$ \\
\hline Total & $\mathbf{5 0}$ \\
\hline
\end{tabular}

Table 4. Parameters and scoring used for block \#609 and real estate \#1

\begin{tabular}{lcc}
\hline Comparison Criteria for Comparable Real Estate Subject to Litigation & Score of Comparable Parcel & $\mathbf{6 0 9 / 1}$ \\
\hline Road, Water, Sewerage, Electricity, Telecom Infrastructure & 20 & 10 \\
\hline Access to Main Roads & 15 & 7.5 \\
\hline Distance to City Center & 25 & 10 \\
\hline Area Size That Makes Sale Attractive & 5 & 5 \\
\hline Parcel Geometry & 5 & 5 \\
\hline Distance to School, Hospital, Religious Facility Areas & 30 & 12 \\
\hline Total & $\mathbf{1 0 0}$ & $\mathbf{5 0}$ \\
\hline
\end{tabular}

study results were found to be 61975669.52 TL. In the expert report, no value decrease was calculated for the remaining part, and according to the results of the study, 1205533.11 TL value decrease was appraised for the remaining part. In the expert's report, no calculations regarding the already attached structures were made. However, in the study conducted, a tree value of 6872.77 TL and a building value of $727633.80 \mathrm{TL}$ were calculated. In this case, the total expropriation value calculated by the Board of Experts was found to be 72447603.55 TL and the total expropriation cost calculated according to the results of the study was 63915709.20 TL. As a result of the incomplete determination of the expert committees, a total of 8531894.35 TL was overestimated in the real estate expropriation reports. The total expropriation cost, which was assessed by the expert committees, resulted in a $13.35 \%$ higher price than it should have been (Table 5).

For the real estate subject to expropriation, the expert reports at the parcel level and the results of the study were compared in terms of price. As a result of the missing determination by the expert committee, it is seen that the real estate was valued at $11834865.96 \mathrm{TL}$ higher than its real value in 21 parcels and 3302971.61 TL less than its real value in 30 parcels. The expert reports and the results of the study were compared at the parcel level, and differences were revealed in terms of price.

Expert reports and study results of 51 real estate subjected to expropriation were examined at the parcel level, and the reasons for the differences were revealed. The main reasons for the difference between the expert reports and the results of the study 
Table 5. 609 Comparison of the expert reports and study results of the real estate in the study area in terms of comparable parcels, unit price and total price

\begin{tabular}{|c|c|c|}
\hline Parameters & Expert Report & Study Result \\
\hline Number of Parcels & 51 & 51 \\
\hline Total Area $\left(\mathrm{m}^{2}\right)$ & 2189926.92 & 2189926.92 \\
\hline Expropriated Area $\left(\mathrm{m}^{2}\right)$ & 145439.66 & 145439.66 \\
\hline Remaining Area $\left(\mathrm{m}^{2}\right)$ & 2044487.26 & 2044487.26 \\
\hline \multirow{3}{*}{ Comparable Value (TL m ${ }^{-2}$ ) } & 1284.34 & \multirow{3}{*}{382.75} \\
\hline & 1287.91 & \\
\hline & 1289.91 & \\
\hline Adjusted Comparable Value $\left(\mathrm{TL} \mathrm{m}^{-2}\right)$ & $216.00-650.00$ & $160.76-631.54$ \\
\hline Total Ground Value & 72447603.55 & 61975669.52 \\
\hline Value of Remaining Value Decrease (TL) & - & 1205533.11 \\
\hline Tree Value (TL) & - & 6872.77 \\
\hline Structure Value (TL) & - & 727633.80 \\
\hline Total Value (TL) & 72447603.55 & 63915709.20 \\
\hline Difference (TL) & $\mathbf{8 5 3 1 8 9 4 . 3 5}$ & \\
\hline Increase Rate (\%) & 13.35 & \\
\hline
\end{tabular}

regarding the real estate are that the zoning features of the real estate (such as no DOP deduction, DOP deduction for a $2^{\text {nd }}$ time, allocation as road, park and forest in the plan) are not fully reflected in the price of the expert reports and the decrease in value due to the project in the remainder after expropriation is not taken into account by the expert committee.

In order to minimize the errors in the values determined by the expert committees, first of all, the people in the expert committees should have the necessary knowledge, experience and training. The establishment of a real estate information system at the parcel level in a way that reflects the real values of real estate throughout Turkey and making it available to the related persons, institutions and organizations will contribute to the fairness of the prices to be determined by the expert committees in determining the cost of the real estate required for land acquisition in investments made by the public and private sectors.

In the evaluation of real estate as per the Expropriation Law, it is at least necessary to take steps to ensure that the necessary information and documents can be obtained by experts and relevant institutions. For example, making a distinction between whether the real estate is land or a land plot, infrastructural studies to easily provide data such as zoning characteristics from the internet will ensure that the errors in the valuation of the real estate are minimized. In order to ensure that the deficiencies and errors in the expert reports determined within the scope of Article 27 of the Expropriation Law No. 2942, amended by the Law No. 4650 of 2001, are corrected in the lawsuits filed within the scope of Article 10 of the same law, both the relevant institution and the owner of the real estate subject to expropriation must raise objections for the deficiencies to be eliminated

\section{Discussion and Conclusion}

Within the scope of the Gelemen and Tekkeköy Logistics Center Railway Connection Line Project examined in the study, the real estate in the expropriation area were primarily classified as land and land plots, and it was determined that all of the 51 real estate subjected to expropriation were land plots. Since the real estate are land type, a precedent survey was conducted. In the study area, in Tekkeköy neighborhood, 2 comparable real estate parcels were identified, and the comparable value found according to the results of the research is $382.75 \mathrm{TL} \mathrm{m}^{-2}$, and when comparable adjustment is made by considering all the positive or negative properties of the real estate, it is seen that the adjusted comparable value varies between $160.76 \mathrm{TL} \mathrm{m}^{-2}$ and $631.54 \mathrm{TL} \mathrm{m}^{-2}$.

It was determined by the expert committees in the study area that 51 real estate parcels qualified as land within the scope of Article 27. For the real estate in the study area, 1 precedent used in the valuation was determined and the comparable value varies between $1284.34 \mathrm{TL} \mathrm{m}^{-2}$ and $1289.91 \mathrm{TL} \mathrm{m}^{-2}$, and it was determined that a comparable adjustment has been made between $216.00 \mathrm{TL} \mathrm{m}^{-2}$ and $650.00 \mathrm{TL} \mathrm{m}^{-2}$. When the expert reports prepared for the real estate in the study area were examined, it is noteworthy that the structures and outbuildings on the 16 real estate subjected to expropriation were not taken into account in the determination of the price, and the price determination without considering the attached structures reveals the deficiency of the explorations made for the real estate. The real estate valuation starts with the identification of the real estate, and it is seen that the deficiency made in the said identification starts with shortcomings in the first stage of real estate valuation and is reflected in the price. The zoning characteristics of the real estate are essentially the most important factor in relation to the value, and the fact that this characteristic is not associated with the value prevents the real value of the real estate from being achieved. It is seen that the price differences especially for the parcels in the study area were appraised without considering the zoning characteristics of the real estate.

The fact that the expert committees used the same comparable parcel for 51 real estate in the study area and that the comparable parcel sales were updated on the Wholesale Price Index instead of the Domestic Producer Price Index (D-PPI) contradicts judicial decisions. The price index taken differently by the expert committees for the real estate chosen as a comparable parcel caused a price difference between all the valuated real estate.

In order to minimize the errors in the values determined by the expert committees, first of all, it emerges that the people in the expert committees should have the necessary knowledge, experience and training. The establishment of a real estate information system at the parcel level in a way that reflects the real values of real estate all around Turkey and making it 
available to the related persons, institutions and organizations will contribute to the fairness of the prices to be determined by the expert committees in determining the cost of the real estate required for land acquisition in investments made by the public and private sectors. In these circumstances, it is considered mandatory that valuation studies should be carried out by real estate development and management experts; such experts should be employed in all public institutions and companies that will provide consultancy services to them; and expert committees to be formed by courts should primarily consist of real estate development and management experts. Lastly, the limitation of this study is that it is hard to obtainthe data, which are court reports, and the data is also very limited.

\section{References}

Açıl AF (1977) Türkiye'de 1950-1974 Yılları Arasında Muhtelif Tarımsal Arazi Nevilerinin Kıymetleri ve Bunlardaki Değişmeler, Ankara Üniversitesi Ziraat Fakültesi Yayınları: 619, Ankara.

Çağan N (1977) Anayasa Mahkemesi ve kamulaştırmada vergi değeri. Ankara Üniversitesi Hukuk Fakültesi Dergisi 411: 247-256.

Denyer-Green B (1998) Compulsory Purchase and Compensation, Fifth Edition, Estates Gazette, London, UK.

Köktürk E, Köktürk E (2016) Taşınmaz Değerlemesi. Seçkin Yayıncılık, Ankara, s. 1374.

Murray WG, Hariss DG, Miller GA, Thompson NS (1983) Farm Appraisal and Valuation. The Iowa State University Press, Sixth Edition, 303, Iowa, USA.

Tanrıvermiș H, Gündoğmuş E, Demirci R (2004) Arazilerin kamulaştırma bedellerinin takdiri tarım arazilerinin kamulaştırma bedellerinin takdirinde kullanılabilecek kapitalizasyon faiz oranları, arazi gelirleri ve arazi birim değerleri. EDUSER Yayınları, Ankara, s. 422 .

Tanrıvermiş H, Aliefendioğlu Y, Demirci R (2011a) Doğanözü Barajı göl alanı ve mücavir sahadaki arazilerin gelirleri ve kapitalizasyon oranları ile birim arazi değerlerinin araştırılması. Ankara Üniversitesi Fen Bilimleri Enstitüsü Taşınmaz Geliştirme Anabilim Dalı Yayın No: 6, Ankara.

Tanrıvermiş H, Aliefendioğlu Y, Demirci R, İşlek BG (2011b) Namazgah Barajı göl alanı ve mücavir alanda arazi gelirleri kapitalizasyon oranın birim arazi değerleri ve kamulaştırma bedellerinin analizi. Ankara Üniversitesi, Fen Bilimleri Enstitüsü Taşınmaz Geliştirme Anabilim Dalı Yayın No: 7, Ankara.

Tanrıvermiş H (2017) Gayrimenkul Değerleme Esasları, SPL Sermaye Piyasası Lisanslama Sicil ve Eğitim Kuruluşu, Lisanslama Sınavları Çalışma Kitapları Ders Kodu: 1014 (Konut Değerleme Sınavı, Gayrimenkul Değerleme Sınavi), Ankara.

Tanrıvermiş H, Aliefendioğlu Y (2019a) The Impacts of Land Acquisition and Resettlement Activities of Infrastructure Investments on Natural and Cultural Heritages and Social and Economic Life: The case of Turkey (Chapter 7), In: Handbook of Contemporary Issues in Expropriation, Eds: Pliemmer and McCluskey, Routledge Taylor \& Francis Group, Oxfordshire, UK, pp:118-157.

Tanrıvermiş H, Aliefendioğlu Y (2019b) Legal and Institutional Fundaments of Expropriation and Compensation Issues in Turkey (Chapter 10), In: Handbook of Contemporary Issues in Expropriation, Eds: Pliemmer and McCluskey, Routledge Taylor \& Francis Group, Oxfordshire, UK, pp: 194-228.

TKGM (2019) Tapu ve Kadastro Genel Müdürlüğü. http://parselsorgu.tkgm.gov.tr. Accessed October 11, 2019.

Tutar M, Pulak TM (2006) Açıklamalı-İçtihatlı-Notlu Karşılaştırmalı Eski-Yeni Kamulaştırma Davaları. Adalet Yayınevi, Ankara, s. 2476.

Ventolo WL, Williams MR (2001) Fundamentals of real estate appraisal. Dearborn Real Estate Education, 8th Edition, 446, Chicago, USA.

Yang WF (1986) Zirai işletmecilikte tetkik ve araştırma metodları. Ege Üniversitesi Ziraat Fakültesi Yayın No: 90, Ege Üniversitesi Matbaası: İzmir, s. 228. 